5. Петренко Л. М. Педагогічне моделювання інформаційно-аналітичної компетентності керівників професійно-технічних навчальних закладів / Л. М. Петренко / Системний аналіз. Інформатика. Управління (САIУ): матеріали III Міжнар. наук.-прак. конф. (м. Запоріжжя, 1416 березня 2012 р.) / Міністерство освіти і науки України, Запорізька обласна державна адміністрація, Академія наук вищої школи України, Класичний приватний університет. Запоріжжя: КПУ, 2012. - С. 225-226.

6. Туряниця 3. В. Формування у майбутніх майстрів виробничого навчання професійнотехнічних навчальних закладів аграрного профілю готовності до професійного самовдосконалення: автореф. дис. ... канд. пед. наук: 13.00 .04 (Туряниця Зоя Василівна; Ін-т проф.-техн. освіти НАПН України. - К., 2017. - 22 с.)

\title{
References
}

1. Varava I. P. AnalIz defInItsIYi "gotovnIst" u kontekstI profesIynoYi pIdgotovki maybutnIh tehnIkIv-programIstIv. VIsnik GluhIvskogo natsIonalnogo pedagogIchnogo unIversitetu ImenI Oleksandra Dovzhenka. PedagogIchnI nauki. 2018. Vip. 2(37). Ch. 2. S. 104-111.

2. Dahin A. N. Modelirovanie kompetentnosti uchastnikov otkryitogo obschego obrazovaniya : avtoref. dis. $\mathrm{Na}$ soiskanie nauch. stepeni d. ped. nauk : spets. 13.00.01 "Obschaya pedagogIka, istoriya pedagogIki i obrazovaniya"/ A. N. Dahin. - Novosibirsk, 2010. - 44 s.

3. Zakon UkraYini "Pro osvItu" /VIdomostI VerhovnoYi Radi. - 2017. - \# 38-39. - $380 \mathrm{~s}$.

4. Obraztsov P. I. Metodyi i metodologiya psihologo-pedagogicheskogo issledovaniya: [ucheb. posob.] / Pavel Ivanovich Obraztsov. - Spb.: Piter, 2004 - 268 s. - (Seriya "Kratkiy kurs"

5. Petrenko L. M. PedagogIchne modelyuvannya Informatslyno-analItichnoYi kompetentnostI kerIvnikIv profesIyno-tehnIchnih navchalnih zakladIv / L. M. Petrenko / Sistemniy analIz. Informatika. UpravlInnya (SAIU): materIali III MIzhnar. nauk.-prak. konf. (m. ZaporIzhzhya, 14-16 bereznya 2012 r.) / MInIsterstvo osvIti I nauki UkraYini, ZaporIzka oblasna derzhavna admInIstratsIya, AkademIya nauk vischoYi shkoli UkraYini, Klasichniy privatniy unIversitet. ZaporIzhzhya: KPU, 2012. - S. 225-226.

6. Turyanitsya Z. V. Formuvannya u maybutnIh maystrIv virobnichogo navchannya profesIynotehnIchnih navchalnih zakladIv agrarnogo profllyu gotovnostI do profesIynogo samovdoskonalennya: avtoref. dis. ...kand. ped. nauk: 13.00.04 (Turyanitsya Zoya VasilIvna; In-t prof.-tehn. osviti NAPN UkraYini. - K., 2017. - 22 s.)

Одержано статтю: 19.10.2018.

Прийнято до друку: 3.12.2018

УДК 378.091.2:[373.3.015.31:502]

DOI:10.15330/esu.14.64-69

\author{
Анастасія Варениченко, \\ асистент, Мелітопольський державний \\ педагогічний університет імені Богдана \\ Хмельницького (м. Мелітополь, Україна) \\ Anastasiia Varenychenko, \\ Assistant, Melitopol Bohdan Khmelnytsky State \\ Pedagogical University (Melitopol, Ukraine) \\ varenychenko2013@gmail.com
}

\section{ПІДГОТОВКА МАЙБУТНЬОГО ВЧИТЕЛЯ ПОЧАТКОВИХ КЛАСІВ ДО ВПРОВАДЖЕННЯ ТРЕНІНГОВИХ ТЕХНОЛОГІЙ В НОВІЙ УКРАЇНСБКІЙ ШКОЛІ}

\section{PREPARATION OF THE FUTURE TEACHER OF PRIMARY SCHOOL FOR THE IMPLEMENTATION OF TRAINING TECHNOLOGIES IN THE NEW UKRAINIAN SCHOOL}

У статті проаналізовані особливості підготовки майбутнього вчителя початкових класів до впровадження тренінгових технологій для формування екологічної культури молодиих иколярів та надана методика проведення різних видів тренінгових вправ: прийняття рімень, саморефлексія, формування практичного досвіду. Наведені вимог до 
вчителя ведучого та структурні елементи проведения психолого-екологічних тренінгів для формування екологічної культури в початкових класах Нової української школи. Виокремлені освітні пришипи для учнів молодшого икільного віку під час проведения природознавчих еколого-психологічних тренінгах.

Ключові слова. Психолого-екологічні тренінги, молодиі иколяри, підготовка вчителя Нової украйнської иколи, тренінгові вправи, структуриі елементи тренінг, вимоги до вчителя ведучого.

The article analyzes the peculiarities of the preparation of the future teacher of primary classes for the introduction of training technologies for the formation of the ecological culture of junior schoolchildren and provided a methodology for conducting various types of training exercises: decision-making, self-reflection, and the formation of practical experience. The requirements are given for the teacher of the leading and structural elements of conducting psychological and environmental trainings for the formation of ecological culture in the elementary classes of the New Ukrainian school. The educational principles are singled out for the pupils of primary school age during the conducting of ecological-psychological trainings of natural sciences. In trainings, the teacher focuses on the formation, development and systematization of the knowledge and skills that children need to perform specific personal, educational or nature-conservation tasks, and seeks to increase the motivation of participants to improve their own academic achievements and behaviors. Ecological and psychological trainings are intended to familiarize the younger generation with existing environmental realities, to encourage it to act, to encourage participation in solving local ecological problems, to interest and equip with ecological knowledge and to form ecological skills. The training sessions are also aimed at developing skills of cooperation and tolerance during group interaction, stimulating emotional emancipation of junior schoolchildren, forming communicative and reflexive qualities in them.

We emphasize that the implementation of most exercises does not require expensive and complex material provision, however, the effectiveness of ecological and psychological training is significantly increased if appropriately arrange a venue (zoo, ecological club, class, etc.).

Key words. Psycho-ecological trainings, junior schoolchildren, teacher training of the New Ukrainian school, training exercises, structural elements of the training, requirements for the teacher of the leader.

Постановка проблеми у загальному вигляді та її зв'язок із важливими науковими чи практичними завданнями. Початок XXI ст. ознаменувався тим, що людство впритул зіткнулося 3 глобальною екологічною кризою, ознаками якої $\epsilon$ суттєво забруднене і зруйноване довкілля, занапащене фізичне і моральне здоров'я людей. Фахівці попереджають, що останнім часом планета “працює на межі" своїх біологічних можливостей і подальша підтримка життєдіяльності людства викликає занепокоєння. За цих умов кожна людина зобов'язана охороняти, зберігати, раціонально використовувати ресурси природи i сприятливі для життя умови довкілля, що актуалізує завдання підготовки екологічно грамотної, свідомої та активної молоді, яка усвідомлює важливість ситуації, глибоко переконана та готова постійно, на кожному кроці, посильно оберігати природу рідного краю, лікувати вже завдані їй рани і запобігати новим. Саме тому в інтересах гармонійного, екологічно безпечного (сталого) розвитку українська держава потребує впровадження новітніх особистісно-орієнтованих технологій навчання.

Аналіз останніх досліджень і публікацій. Вагомим доробком у царині порушеної проблеми стали дослідження цілого грона українських учених щодо важливості підготовки майбутнього вчителя початкових класів до впровадження 
тренінгових технологій в Новій українській школі. У працях Горяна Л.Г., Хрутьба В.О., Малько Г.О., Свдокимова Н.О., Швалб Ю.М., Кочерга О.М., Семенова А.В., Дерябо С.Д., Мелаш В.Д. та Ясвіним В.А. обгрунтовано ефективні інтерактивні технології, а саме еколого-психологічні тренінги, призначених для формування екологічної культури в учнів Нової української школи.

Відповідно, до зазначеного вище мету статті вбачаємо в обгрунтуванні важливості підготовки майбутнього вчителя початкових класів до впровадження тренінгових технологій в Новій українській школі.

Виклад основного матеріалу. Визначальною ланкою цілісної системи безперервної екосвіти $є$ Нова українська школа, як основний навчально-виховний інститут суспільства, яка повинна і має можливість забезпечити учнів необхідним обсягом знань, умінь та навичок, прищепити їм цінності суспільства сталого розвитку, навчити приймати самостійні рішення щодо збереження природи, дотримуватися принципів соціальної справедливості, сформувати екологічну компетентність та екологічно збалансовану поведінку.

Повномірно використовувати творчу обдарованість, уяву, ігровий потенціал, пізнавальну активність молодших школярів в процесі випереджаючої екологічної освіти для сталого розвитку дозволяють новітні особистісно-орієнтовані технології навчання [1, с. 116]. Значного освітнього ефекту сучасні педагоги досягають застосовуючи "інтенсивне навчання практичного спрямування", яким $є$ тренінги. Навчання на тренінгах дуже цінне, адже не потребує від школярів спеціальних знань та вмінь, актуалізує та збагачує наявний життєвий досвід та створює можливості для прямої взаємодії з екологічними реаліями рідного краю, держави, світу.

На сьогоднішній день, відчувається гострий дефіцит методичних розробок еколого-психологічних тренінгів для вчителів початкової школи. Дієвим інструментом формування високого рівня екологічної культури школярів $\epsilon$ технологія тренінгового навчання, в якій поєднуються елементи активного та інтерактивного навчання та домінують активно-діяльнісний, компетентнісно-зорієнтований та особистісно-зорієнтований способи навчання.

“Тренінг" трактується як навчання, виховання, тренування, підготовка. На тренінгах вчитель зосереджує зусилля на формуванні, розвитку і систематизації знань та навичок, які знадобляться дітям для виконання конкретних особистісних, навчальних або природозберігаючих завдань, та прагне посилити мотивацію учасників до удосконалення власних навчальних досягнень та поведінки.

Ця форма організації навчально-виховної роботи передбачає планомірне проведення різноманітних вправ, які призначені стимулювати учня до засвоєння практичних умінь та навичок щодо вирішення завдань, запропонованих вчителем, а також залучають його до пошуку шляхів виходу із складних екологічних ситуацій, подолання певних життєво важливих проблем тощо. В ході тренінгу вчитель використовує наявні досвід i знання школярів, створює позитивну емоційну атмосферу в групі, прагне ефективно використати різні методи навчання (домінують активні та інтерактивні) для набуття сформованих довкіллязберігаючих навичок та екологічних компетенцій, які стають фундаментом їхньої екологічної культури.

Еколого-психологічні тренінги призначені виконувати такі функції: 1. формувати i розвивати екологічні настанови особистості, серед яких пріоритетною $\epsilon$ подолання антропоцентричного, прагматичного ставлення до природних ресурсів; 2. коригувати цілі взаємодії особистості з об'єктами природи; 3. навчати умінням і навичкам екологічно виваженої взаємодії з довкіллям; 4. розвивати можливості 
безпосереднього чуттєвого сприйняття школярів під час їхніх контактів з природним середовищем; 5. розширювати індивідуальний екологічний простір.

Зазначимо, що під час природознавчих еколого-психологічних тренінгах вчитель втілює важливі освітні принципи для молодших школярів: 1. принцип партнерського спілкування; 2. принцип врахування пізнавальних інтересів дітей; 3. принцип пізнавальної активності учасників; 4. принцип дослідницької позиції учнів; 5. принцип об’єктивності екологічної поведінки та діяльності; 6. принцип глобально-регіонально-краєзнавчого змісту навчання.

Слід зазначити, що до кваліфікації та особистості педагога (ведучого тренінгу) пред'являються дуже високі вимоги; зокрема він має мати достатній багаж загальнобіологічних, методичних та психологічних знань та умінь, конкретних натуралістичних умінь, досвід проведення психолого-екологічних тренінгів. Методично вірно побудовані еколого-психологічні тренінги дозволяють максимально задіяти самостійність школярів. При цьому ведучий лише інформує учасників 3 приводу розглядуваної проблеми (надає теоретичний матеріал) та організовує іï самостійне обговорення серед учнів, залучаючи їх до пошуку кроків для іiі вирішення. Ведучий-тренер формує психологічно комфортні групи із 8-12 учнів.

В ході еколого-психологічного тренінгу учні, переважно в формі рольових ігор-експромтів, виконують різноманітні практичні завдання, розв'язують проблемні ситуації та готують коротенькі інформаційні повідомлення, на матеріалі яких організовуються дискусії. Щоб не перевантажувати школярів та домогтися ефективнішого засвоєння навчального матеріалу, технологія тренінгового навчання передбачає чергування теоретичних (інформування), практичних (виконання вправ) та ігрових етапів [4, с. 99].

Важливою та обов'язковою складовою тренінгових занять $є$ практичні завдання та вправи, які передбачають спеціально або частково структуровану, заздалегідь сплановану або імпровізовану пізнавальну діяльність школярів, спрямовану на досягнення запланованих ведучим групових або особистісних цілей. 3 молодшими школярами доцільно практикувати: 1. вправи на знайомство; 2. рефлексивні вправи у вигляді відповідей на запитання “Як ти ставишся до...”, “Що ти відчуваєш, коли...”; 3. рухливі вправи; 4. вправи для створення групових рішень тощо [2, с. 262].

На нашу думку, для формування екологічної культури молодших школярів під час еколого-психологічних тренінгів 3 природознавства найкраще використовувати наступні види вправ:

1. Вправи на прийняття рішень. Ведучий залучає учнів до аналізу та розв'язання (в ході індивідуальної або групової пізнавальної діяльності, дискусії) конкретних життєвих ситуацій $з$ подальшими екологічними наслідками. При цьому важливо допомогти учням усвідомити заплановану педагогом мету вправи та сформувати прагнення іiі досягти. При виконанні таких вправ учні висловлюють власні переконання та цільові настанови, активно шукають способи вирішення поставленої проблеми, обирають свою стратегію поведінки, яка може суттєво відрізнятися від звичної та загальноприйнятої. Педагогічна цінність таких вправ полягає в тому, що вони на націлені на усвідомлення молодшими школярами особистої причетності до екологічних проблем, формують і вдосконалюють їхні вміння приймати відповідальні екологічно вивірені рішення.

2. Вправи на саморефлексію змушують учня аналізувати та переосмислювати особисті переконання та суб'єктивне ставлення до об'єктів природи і своїх дій, моделювати бажане (очікуване) майбутнє, допомагають йому краще зрозуміти 
мотиви своєї поведінки та дій. Для цього педагог викликає у дітей глибокі та дієві позитивні або негативні емоції. До таких вправ належать “Майбутнє, якого я прагну", "Природа в моєму житті" тощо.

3. Вправи для формування практичного досвіду. Учні залучаються до екологічно спрямованої діяльності, проведення самостійних досліджень таким чином, щоб вони вчилися втілювати свої екологічні переконання в екологічно грамотних вчинках, щоб в повсякденному житті вони практикували екологічно збалансовану діяльність, щоб їхн поведінка враховувала екологічні закономірності та норми. Варто зазначити, що технологія тренінгового навчання потребує, щоб зміст занять передбачав розгляд поряд 3 глобальними, передусім, регіональних екологічних проблем, які стосуються найближчого до молодших школярів природно-техногенного оточення. Педагог повинен добирати і насичувати тренінг екологічними знаннями (інформацією) побутово-повсякденного характеру за глобально-регіонально-краєзнавчим принципом. У такий спосіб досягається усвідомлення дітьми своєї причетності до існуючих екопроблем та здатності впливати на екологічний стан довкілля, зокрема через мінімізацію власного споживання, через поліпшення умов існування місцевих рослин і тварин.

Також, необхідно виокремити структурні елементи тренінгових занять: 1. постановка загальних та особистісних освітніх цілей; 2. пояснення, розповідь, інформування ведучого щодо суті розглядуваного питання; 3. виконання учасниками тренінгу практичних занять та вправ; 4. обговорення запланованого питання та результатів виконаних вправ; 5. підбиття підсумків заняття.

Цінним $\epsilon$ те, що у ході еколого-психологічного тренінгу учні початкових класів отримують можливість практикуватись, моделювати ситуацію, експериментувати, перевіряти й узгоджувати з ведучим свої висновки, шліфувати навички спілкування та взаємодії $з$ довкіллям, аналізувати власні досягнення і поведінку. Це дозволяє їм у подальшому уникнути помилок в реальному житті, допомагає швидше приймати оптимальні екологічно вивірені рішення [3, с. 37].

Таким чином, функціональні переваги, змістове наповнення, специфіка структури та переважно активно-діяльнісні методи навчання на еколого-психологічних тренінгах гарантують високий освітній результат - розширення зони персональної відповідальності кожного школяра за стан довкілля, формування, передусім, побутово-повсякденного рівня екологічної культури, як фундаменту для гармонійних стосунків $з$ природним та суспільним оточенням в інтересах стійкого розвитку.

Висновки. Аналіз методичних переваг еколого-психологічних тренінгів, які, на нашу думку, дозволяють отримувати гарантовано високі результати в напрямку формування екологічної культури молодших школярів, в подальшому спонукатиме нас зосередити зусилля на детальній розробці методичних рекомендацій до організації пакета природознавчих тренінгів екологічного спрямування для молодшого шкільного віку, та готовності вчителя до впровадження тренінгових технологій в Новій українській школі.

\section{Література}

1. Кочерга О. М. Особливості використання тренінгових технологій у процесі формування практичної компоненти професійної підготовки майбутнього вчителя / О. М. Кочерга // Молодий вчений. - 2014. - № 2 (лютий). - С. 116-119.

2. Мелаш В.Д. Методична підготовка майбутнього вчителя початкової школи до формування екологічної компетентності в умовах Нової української школи / А.Б. Варениченко, К.С. Безталанна / Вісник Чернігівського національного педагогічного університету імені 
Т.Г. Шевченка / [ред. кол. : Носко М.О. (гол. ред.) та ін.]. - Чернігів: ЧНПУ, 2018. - Вип.151. В 2-х томах. Том 1. - С. 262-266 (Серія: педагогічні науки)

3. Підготовка майбутніх педагогів до реалізації екологічної освіти для сталого розвитку : навч.метод. посіб. / [В. Д. Мелаш, О. В. Гнатів, Н. В. Вахняк та ін.]; за заг. ред. В. В. Молодиченко. - Мелітополь, 2016. - 215 с. (Серія: "Екологічна освіта для сталого розвитку")

4. Типові освітні програми для закл. Загальної середньої освіти: 1-2 класи. - ТД "ОСВІТАЦЕНТР+", 2018. - $240 \mathrm{c}$.

\section{References}

1. Kocherha O. M. Osoblyvosti vykorystannya treninhovykh tekhnolohiy u protsesi formuvannya praktychnoyi komponenty profesiynoyi pidhotovky maybutnoho vchytelya / O. M. Kocherha // Molodyy vchenyy. - 2014. - № 2 (lyutyy). - S. 116-119.

2. Melash V.D. Metodychna pidhotovka maybutn'oho vchytelya pochatkovoyi shkoly do formuvannya ekolohichnoyi kompetentnosti $\mathrm{v}$ umovakh Novoyi ukrayinskoyi shkoly / A.B. Varenychenko, K.S. Beztalanna / Visnyk Chernihivskoho natsionalnoho pedahohichnoho universytetu imeni T.H. Shevchenka / [red. kol. : Nosko M.O. (hol. red.) ta in.]. - Chernihiv: CHNPU, 2018. - Vyp.151. - V 2-kh tomakh. Tom 1. - S. 262-266 (Seriya: pedahohichni nauky)

3. Pidhotovka maybutnikh pedahohiv do realizatsiyi ekolohichnoyi osvity dlya staloho rozvytku : navch.-metod. posib. / [V. D. Melash, O. V. Hnativ, N. V. Vakhnyak ta in.]; za zah. red. V. V. Molodychenko. - Melitopol, 2016. - 215 s. (Seriya: "Ekolohichna osvita dlya staloho rozvytku")

4. Typovi osvitni prohramy dlya zakl. Zahalnoyi serednoyi osvity: 1-2 lasy. - TD "OSVITATSENTR+", 2018. $-240 \mathrm{~s}$.

Одержано статтю: 1.10 .2018

Прийнято до друку: 25.10.2018

УДК $[37.09+373.2]: 378.22$

DOI:10.15330/esu.14.69-76

\section{Катерина Волинець,}

кандидат педагогічних наук, доцент,

Київський університет імені Бориса Грінченка

(м. Київ, Україна)

Kateryna Volynets,

Candidate of pedagogical sciences $(\mathrm{PhD})$,

Associate Professor, Boris Grinchenko Kiev University

(Kiev, Ukraine)

ekaterina_volinec@ukr.net

\section{ПІДГОТОВКА МАГІСТРІВ ДО УПРАВЛІННЯ ІННОВАЦЙНОЮ ДІЯЛЬНІСТЮ ЗАКЛАДУ ДОШКІЛЬНОЇ ОСВІТИ}

\section{TRAINING OF MASTERS TO MANAGEMENT OF INNOVATIVE ACTIVITY OF THE INSTITUTION OF PRESCHOOL EDUCATION}

У статті розкрито деякі аспекти професійної підготовки майбутніх магістрів до управління інноваційною діяльністю закладу дочкільної освіти. Визначено поняття управління інновачійною діяльністю закладу доикільної освіти. Безпосередній вплив на прочес професійної підготовки майбутніх магістрів мають інновачійний потенчіал особистості магістра та інновачійний потенціал закладу вищої освіти. Розкрито зміст, форми і методи організачії наукової роботи в закладі вищої освіти та форми залучення магістрів до наукової діяльності під час навчания. Обгрунтовано сутність, спечифіку, значуиість інновачій та інновачійної діяльності педагогічного колективу закладу освіти в ринкових умовах. Виокремлено проблеми організацій інноваційної діяльності та ї здійснения. обтрунтовано вимоги до сучасного керівиика закладу дошкільної освіти та формування змісту підготовки майбутніх магістрів до управління інноваційною діяльністю закладу доикільної освіти. 